\title{
NOTES
}

\section{STRUCTURE OF ANTIBIOTIC Bu-2545, A NEW MEMBER OF THE CELESTICETIN-LINCOMYCIN CLASS}

\author{
Soichiro Toda, Susumu Nakagawa, \\ Takayuki Naito and Hiroshi Kawaguchi \\ Bristol-Banyu Research Institute, Ltd. \\ Meguro, Tokyo, Japan
}

(Received for publication February 9, 1981)

$\mathrm{Bu}-2545$ is a new antibiotic that has activity against various anaerobic organisms as well as aerobic Gram-positive bacteria. It was produced by a Streptomyces strain similar to $S$. aureocirculatus. The fermentation, isolation and properties of $\mathrm{Bu}-2545$ were reported in a preceding paper $^{1)}$. The structure of Bu- 2545 had been proposed $^{1)}$ on the basis of microanalysis, NMR and mass spectral data in comparison with lincomycin and celesticetin. The present paper describes the structure elucidation of $\mathrm{Bu}-2545$, including its stereochemistry, by ${ }^{13} \mathrm{C}-\mathrm{NMR}$ and degradation studies.

The ${ }^{13} \mathrm{C}-\mathrm{NMR}$ spectrum of Bu-2545 (1) (Table 1) showed the presence of sixteen carbons including C- $\mathrm{CH}_{3}$ ( $\delta$ in ppm: 14.0), $\mathrm{SCH}_{3}(14.0), \mathrm{NCH}_{3}$ (41.4) and $\mathrm{OCH}_{3}$ (56.9). The carbon chemical shifts due to $\mathrm{SCH}_{3}$ and $\mathrm{C}-1 \sim \mathrm{C}-5$ of the sugar portion were in agreement with those of lincomycin (2) under protonated conditions. However, the signals due to $\mathrm{C}-6 \sim \mathrm{C}-8$ and the $\mathrm{N}$ acyl residue consisting of six carbons were different from those of 2 . The C-7 signal of $\mathbf{1}$ at $\delta 76.8$ was shifted downfield by $9.4 \mathrm{ppm}$ as compared with that of $\mathbf{2}$, while the C-6 and C-8 signals were shifted upfield by 5.0 and $3.2 \mathrm{ppm}$, respectively. These three carbons along with the N-

Table 1. CMR spectra of Bu-2545 and related compounds.

\begin{tabular}{|c|c|c|c|c|c|c|c|c|}
\hline & \multicolumn{8}{|c|}{ Chemical shift, ppm from TMS } \\
\hline & \multirow{2}{*}{ Carbon } & \multicolumn{2}{|c|}{ Bu-2545 (1) ${ }^{\mathrm{a}}$} & \multicolumn{2}{|c|}{$5^{a}$} & \multirow{2}{*}{$\begin{array}{l}\text { Lincomycin } \\
\mathrm{HCl}(\mathbf{2})^{\mathrm{b}}\end{array}$} & \multirow{2}{*}{$\begin{array}{l}\text { Celesticetin } \\
\mathrm{HCl}(\mathbf{3})^{\mathrm{c}}\end{array}$} & \multirow{2}{*}{$\begin{array}{l}\text { Methyl thio- } \\
\text { lincosaminide } \\
\mathrm{HCl}(8)^{\mathrm{a}}\end{array}$} \\
\hline & & Base & $+\mathrm{DCl}$ & Base & $+\mathrm{DCl}$ & & & \\
\hline \multirow{10}{*}{$\begin{array}{l}\text { The sugar } \\
\text { moiety }\end{array}$} & 1 & $89.2(\mathrm{~d})^{\mathrm{d}}$ & 89.1 & $88.9(\mathrm{~d})^{\mathrm{d}}$ & 88.8 & 89.2 & 88.3 & 88.7 \\
\hline & 2 & $69.7(\mathrm{~d})$ & 69.1 & $68.6(d)$ & 68.2 & 68.8 & 70.3 & 68.3 \\
\hline & 3 & $71.3(\mathrm{~d})$ & 71.2 & $71.3(\mathrm{~d})$ & 70.6 & 71.4 & 71.3 & 70.7 \\
\hline & 4 & $70.0(d)$ & 69.5 & $69.2(\mathrm{~d})$ & 69.7 & 69.5 & 69.9 & 69.5 \\
\hline & 5 & $69.3(\mathrm{~d})$ & 69.8 & $71.7(d)$ & 67.3 & 70.0 & 69.3 & 68.1 \\
\hline & 6 & $49.0(\mathrm{~d})$ & 49.9 & $50.4(\mathrm{~d})$ & 54.8 & 54.9 & 50.8 & 56.9 \\
\hline & 7 & $76.7(d)$ & 76.8 & $77.4(\mathrm{~d})$ & 74.7 & 67.4 & 76.7 & 65.7 \\
\hline & 8 & $14.0(q)$ & 14.0 & $12.5(\mathrm{q})$ & 14.3 & 17.2 & 14.7 & 17.7 \\
\hline & $\mathrm{SCH}_{3}$ & $14.0(\mathrm{q})$ & 14.0 & $13.9(\mathrm{q})$ & 13.6 & 14.2 & -- & 13.6 \\
\hline & $\mathrm{OCH}_{3}$ & $56.7(\mathrm{q})$ & 56.9 & $56.3(\mathrm{q})$ & 57.0 & - & 56.9 & - \\
\hline \multirow{6}{*}{$\begin{array}{c}\text { The amino } \\
\text { acid } \\
\text { moiety }\end{array}$} & $1^{\prime}$ & $177.3(\mathrm{~s})$ & 169.4 & & & 170.1 & 169.1 & \\
\hline & $2^{\prime}$ & $68.9(\mathrm{~d})$ & 68.5 & & & 69.5 & 68.5 & \\
\hline & $3^{\prime}$ & $30.9(\mathrm{t})$ & 30.5 & & & 36.4 & 30.8 & \\
\hline & $4^{\prime}$ & $23.9(t)$ & 23.4 & & & 37.4 & 23.9 & \\
\hline & $5^{\prime}$ & $56.7(t)$ & 57.3 & & & 62.4 & 57.7 & \\
\hline & $\mathrm{NCH}_{3}$ & $41.1(\mathrm{q})$ & 41.4 & & & 41.8 & 41.9 & \\
\hline
\end{tabular}

a Recorded by a Varian FT-80 spectrometer at $20 \mathrm{MHz}$ in $\mathrm{D}_{2} \mathrm{O}$ with dioxane as an internal reference.

b See ref. 4. The shifts of $n$-propyl on the $\mathrm{N}$-acyl residue are omitted.

c See ref. 4. The shifts of $\beta$-salicyloxyethylthio in the 1-position of the sugar moiety are omitted.

d Multiplicity of resonance in single frequency off-resonance proton-decoupled spectrum. 
Fig. 1. Bu-2545 and related antibiotics.

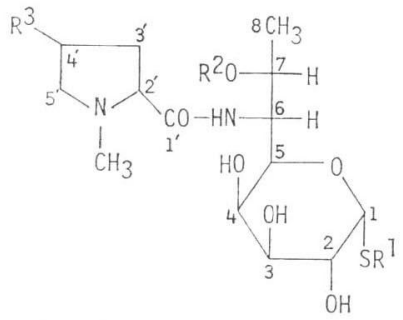

\begin{tabular}{|c|c|c|c|c|}
\hline & Antibiotic & $\mathrm{R}^{1}$ & $\mathrm{R}^{2}$ & $\mathrm{R}^{3}$ \\
\hline 1 & Bu-2545 & $\mathrm{CH}_{3}$ & $\mathrm{CH}_{3}$ & $\mathrm{H}$ \\
\hline 2 & Lincomycin & $\mathrm{CH}_{3}$ & $\mathrm{H}$ & $n-\mathrm{C}_{3} \mathrm{H}_{7}$ \\
\hline 3 & Celesticetin & & $\mathrm{CH}_{3}$ & $\mathrm{H}$ \\
\hline
\end{tabular}

acyl and $\mathrm{O}-\mathrm{CH}_{3}$ carbons of $\mathbf{1}$ showed a good agreement with those of celesticetin $(3)^{4)}$. This is consistent with the proposed structure in the previous paper ${ }^{1)}$, where the 7-hydroxy group of the methyl thiolincosaminide moiety is methylated and the 6-amino group acylated with
$\mathrm{N}$-methylproline (hygric acid) as in $\mathbf{3}$.

Hydrolysis of 1 with $6 \mathrm{~N}$ hydrochloric acid (reflux, 3 hours) followed by purification on Amberlite IR-120 gave L-hygric acid (4) (45\% yield) as colorless needles, mp $114 \sim 114.5^{\circ} \mathrm{C}$ (Ref. ${ }^{5}$ ) $\left.116^{\circ} \mathrm{C}\right), m / z 129\left(\mathrm{M}^{+}\right),[\alpha]_{\mathrm{D}}^{25}-82.5^{\circ}\left(c 1.0, \mathrm{H}_{2} \mathrm{O}\right)$ [Ref. ${ }^{5)}-80.1^{\circ}\left(c 2, \mathrm{H}_{2} \mathrm{O}\right)$ ], which was identical in all respects with L-hygric acid prepared from Lproline by $\mathrm{N}$-methylation with formaldehyde and sodium cyanoborohydride.

It has been reported ${ }^{(6)}$ that hydrazinolysis of $\mathbf{2}$ at reflux temperature cleaved the amide bond and liberated the sugar and amino acid moieties without rearrangement or racemization. Thus, 1 was subjected to a similar hydrazinolysis (reflux for 2 days) and following chromatographic separation on a silica gel column afforded a basic substance (5, $\mathrm{C}_{10} \mathrm{H}_{21} \mathrm{NO}_{5} \mathrm{~S}$ ) having no amide band in the IR, along with $\mathrm{N}$-methylproline hydrazide (6) which gave 4 by $6 \mathrm{~N} \mathrm{HCl}$ hydrolysis (overall yield of $4,35 \%$ ).

Compound $\mathbf{5}$ was compared with methyl thiolincosaminide (8) which was prepared from 2 by a reported procedure ${ }^{6)}$. The PMR spectrum

Fig. 2. Degradation reaction of Bu-2545.

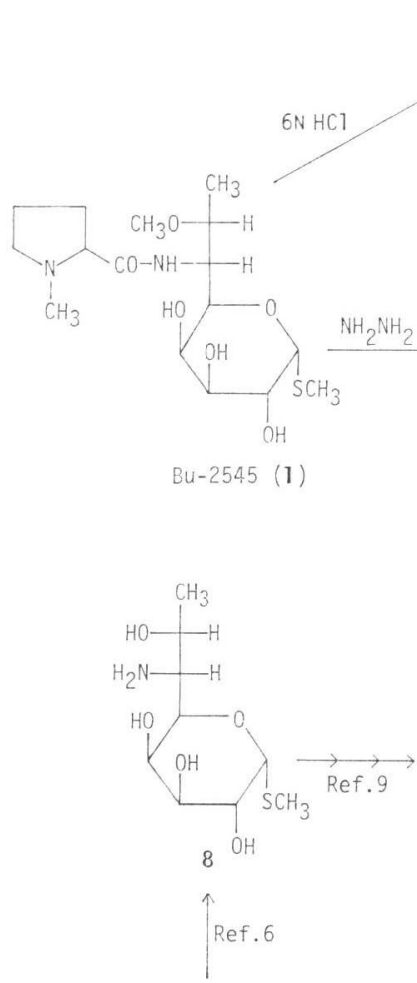

Lincomycin (2)
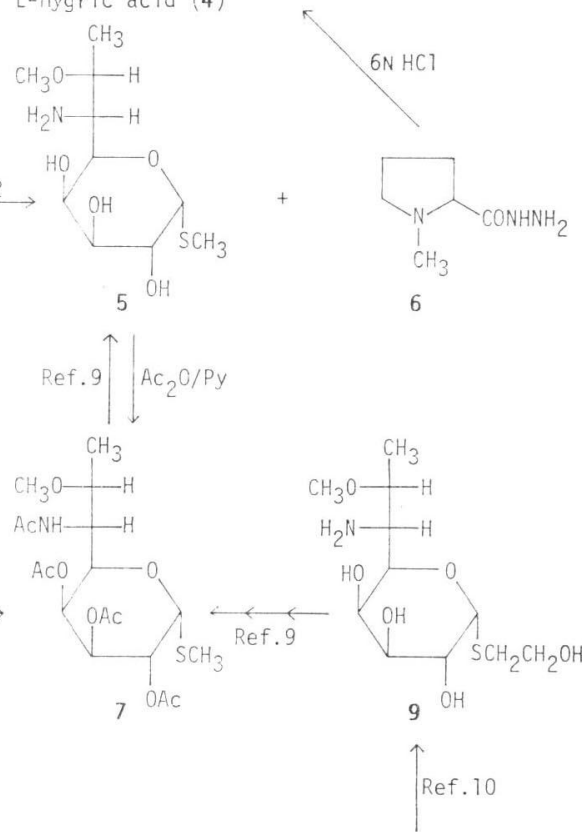

Celesticetin (3) 
Table 2. Major signals in PMR spectra of $\mathbf{5}$ and $8\left(60 \mathrm{MHz}, \mathrm{D}_{2} \mathrm{O}\right)$.

\begin{tabular}{l|l|l}
\hline \multirow{2}{*}{ Proton } & \multicolumn{2}{|c}{ Chemical shift, $\delta$ (ppm from DSS) } \\
& \multicolumn{1}{|c|}{$\mathbf{5}$} & \multicolumn{1}{|c}{$\mathbf{8}$} \\
\hline $\mathrm{CH}-\mathrm{CH}_{3}$ & $1.15(\mathrm{~d}, J=6.5 \mathrm{~Hz})$ & $1.13(\mathrm{~d}, J=6.5 \mathrm{~Hz})$ \\
$\mathrm{S}-\mathrm{CH}_{3}$ & $2.11(\mathrm{~s})$ & $2.12(\mathrm{~s})$ \\
$\mathrm{O}-\mathrm{CH}_{3}$ & $3.32(\mathrm{~s})$ & - \\
Anomeric $\mathrm{H}$ & $5.28(\mathrm{~d}, J=5.5 \mathrm{~Hz})$ & $5.33(\mathrm{~d}, J=5.5 \mathrm{~Hz})$ \\
\hline
\end{tabular}

$\left(60 \mathrm{MHz}, \mathrm{D}_{2} \mathrm{O}\right)$ of $\mathbf{5}$ (Table 2) showed signals assignable to $>\mathrm{CH}-\mathrm{CH}_{3}$ and $\mathrm{S}-\mathrm{CH}_{3}$ groups as well as an anomeric proton, which were also observed in the spectrum of $\mathbf{8}^{7)}$, and, in addition, indicated the presence of an $\mathrm{O}-\mathrm{CH}_{3}$ singlet at $\delta$ 3.32. The CMR spectrum of $\mathbf{5}$ (Table 1) which included 10 carbon signals was similar to that of $\mathbf{8}$ in the $\mathrm{C}-1 \sim \mathrm{C}-5$ signals. The $\mathrm{C}-7$ signal of $\mathbf{5}$ located at 9.0 ppm lower field than that of 8 and the C-6 and C-8 signals of 5 shifted to the higher field by $2.1 \mathrm{ppm}$ and $3.4 \mathrm{ppm}$, respectively, than those of 8 . These observations and an $\mathrm{O}-\mathrm{CH}_{3}$ signal at $\delta 57.0$ in $\mathbf{8}$ indicated a methoxy group present at the $\mathrm{C}-7$ position of $\mathbf{8}$. The mass spectrum of 5 (Fig. 3) indicated the $\mathrm{M}^{+}$ion at $\mathrm{m} / \mathrm{z}$ 267 and an intense peak at $m / z 88$ due to cleavage between C-5 and C- 6 . These peaks of $\mathbf{5}$ were higher by 14 mass units than the corresponding peaks of $\mathbf{8}^{8)}$, whereas the base peak at $m / z 208$ due to cleavage between C-6 and C-7 was common to both $\mathbf{5}$ and $\mathbf{8}$. This also supported the location of a methoxy group at the 7-position of $\mathbf{8}$.

The above spectral data suggested that $\mathbf{5}$ was methyl 7-O-methyl thiolincosaminide or its 7epimer. Methyl 7-O-methyl-1-thio- $\alpha$-lincosami-

Fig. 3. Diagnostic peaks in mass spectrum of $\mathbf{5}$ and $\mathbf{8}$.

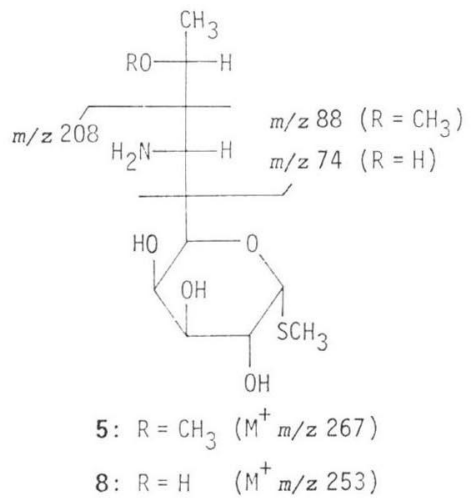

nide has been reported ${ }^{9)}$ to be prepared from the tetra-N,O-acetate (7) derived from lincomycin and celesticetin via $\mathbf{8}$ and 2-hydroxyethyl 1-thio- $\alpha$ celestosaminide $(9)^{10)}$, respectively. The identities of $\mathbf{5}$ and its tetra-N,O-acetate (7) with those reported in literature were verified by melting point and specific rotation data: 5: mp 127 $128^{\circ} \mathrm{C}$ (Ref. $\left.{ }^{9)}, 126 \sim 126.5^{\circ} \mathrm{C}\right) ;[\alpha]_{\mathrm{D}}^{23}+250^{\circ}(c 0.3$, $\left.\mathrm{H}_{2} \mathrm{O}\right)\left[\operatorname{Ref}^{9}{ }^{g)},[\alpha]_{\mathrm{D}}+263^{\circ}\left(c 0.83, \mathrm{H}_{2} \mathrm{O}\right)\right] . \quad 7: \mathrm{Ac}_{2} \mathrm{O} /$ Pyridine; yield $82 \%$; mp $211 \sim 213^{\circ} \mathrm{C}$ (Ref. ${ }^{\circ)}$, $\left.211.5 \sim 213^{\circ} \mathrm{C}\right) ;[\alpha]_{\mathrm{D}}^{25}+234^{\circ}\left(c 0.5, \mathrm{CHCl}_{3}\right)\left[\mathrm{Ref}^{\circ)}{ }^{\circ)}\right.$, $\left.[\alpha]_{\mathrm{D}}+229^{\circ}\left(c 0.72, \mathrm{CHCl}_{3}\right)\right] ; \mathrm{M}^{+} \mathrm{m} / z$ 435; $\nu_{\mathrm{c}=0}$ $1755,1660 \mathrm{~cm}^{-1}$.

Thus, the sugar part of $\mathrm{Bu}-2545$ was found to have the same stereochemistry as that of lincomycin and celesticetin. Accordingly, the structure of Bu-2545 was established as 7-O-methyl4 -de- $n$-propyllincomycin or methyl 6-N-(1methyl-L-prolyl)-1-thio- $\alpha$-celestosaminide.

\section{References}

1) Hanada, M.; M. Tsunakawa, K. Tomita, H. Tsumiura \& H. Kawaguchi: Antibiotic Bu2545 , a new member of the celesticetin-lincomycin class. J. Antibiotics 33: $751 \sim 753,1980$

2) Herr, R. R. \& G. Slomp: Lincomycin. II. Characterization and gross structure. J. Am. Chem. Soc. 89: 2444 2447, 1967

3) Hoeksema, H. ; G. F. Crum \& W. H. DeVeries: Isolation and purification of celesticetin. Antibiot. Ann. 1954/1955: 837 841, 1955

4) Mizsak, S.; G. Slomp, A. Neszmelyi, S. D. Gero \& G. LuKacs: Carbon-13 NMR spectral analysis and spin-lattice relaxation times of the antibiotic lincomycin and related compounds. Tetrahed. Lett. 1977: 721 724, 1977

5) Karrer, P. \& R. Widmer: Configuration of nicotine. Optically active hygric acid. Helv. Chem. Acta 8:364 368, 1925

6) Schroeder, W.; B. BanNister \& H. Hoeksema : Lincomycin. III. The structure and stereochemistry of the carbohydrate moiety. J. Am. Chem. Soc. 89: 2448 2453, 1967

7) Slomp, G. \& F. A. MacKellar: Lincomycin. IV. Nuclear magnetic resonance studies on the structure of lincomycin, its degradation products, and some analogs. J. Am. Chem. Soc. 89: $2454 \sim 2459,1967$

8) Kagan, F. \& M. F. Grostic: Mass spectra of lincomycin, lincomycin analogs and degradation products. Org. Mass Spectrometry 6: $1217 \sim 1223,1972$

9) BAnNister, B.: Modifications of lincomycin 
involving the carbohydrate portion. III. The 7-O-methyl and 6-de-(1-hydroxyethyl) analogues. J. Chem. Soc. Perkin I 1973: 1676 1682, 1973
10) Hocksema, H.: Celesticetin. IV. The structure of celesticetin. J. Am. Chem. Soc. 86: $4224 \sim 4225,1964$ 